\title{
Natuurrampe en die voorsienigheid van God, met besondere verwysing na die beskouing van Johannes Calvyn ${ }^{1}$
}

P C Potgieter $^{2}$

(Universiteit van die Vrystaat)

\section{ABSTRACT \\ Natural disasters and the providence of God, with special reference to the views of John Calvin}

It stands to reason that many of those believing in the providence of God will look for theological guidance when natural disasters of a catastrophic magnitude strike. This paper explores the reasoning of well-known theologians, and particularly John Calvin, in this regard endeavouring to develop a relevant contribution towards deeper insight in the extremely difficult issue of a theodicy. Contrary to a popular idea that Calvin adopted an extremely harsh line on providence by which God becomes responsible for every kind of disaster, it is argued that he maintains a fine balance between the loving grace of our heavenly Father and his righteous judgment over mankind who undermined his intended order of nature by sin. Argued from a Christological perspective, the faithful should respect both God's revelation and his hidden plan, which they will not be able to fathom in this life. Whatever happens, they should be pastorally guided to humble patience and perseverance in sincere hope on God's unquestionable faithfulness, and the firm belief that he will guide his creation to its true destination.

\section{INLEIDING}

Ek sou dit waarskynlik vir myself heelwat makliker gemaak het deur ' $n$ ander onderwerp vir hierdie lesing te kies. Maar daar is meer as een rede waarom ek dit tog wil hê oor die plek van katastrofale natuurrampe binne die voorsienigheid van God.

Na die Indiese Oseaan aardbewing en die daaropvolgende tsunami teen die einde van 2004 het ek nogal intensief gaan kyk na wat Johannes Calvyn in sy verskillende geskrifte oor natuurrampe

1 Johan Heyns gedenklesing - 24 Mei 2006 aan die Fakulteit Teologie, Universiteit van Pretoria.

2 Navorsingsgenoot, Departement Dogmatologie, Universiteit van die Vrystaat. 
sê. Dit was uiteindelik ' $n$ stuk navorsing wat my besonder geboei het $^{3}$.

Ek het ook weer ' $n$ keer begin kyk na wat ander teoloë hieroor te sê het. Dit het my veral getref dat teoloë oor die algemeen in die behandeling van die problematiek van die voorsienigheidsleer veral aandag gee aan die rampspoed wat deur die mens se toedoen ontstaan, terwyl daar dikwels maar net terloops geraak word aan katastrofes wat nie aan menslike optrede toegeskryf kan word nie.

Johan Heyns het as skerpsinnige teoloog self nie teruggedeins van moeilike teologiese vraagstukke soos hierdie nie. Daarom sê hy onomwonde:

"Die gebeure waaraan ons lewe onderwerp is, is so dubbelsinnig en by tye selfs so evident onsinnig dat dit moeilik te rym is met die Bybelse God van liefde en orde. Die katastrofale gebeurtenisse van natuurrampe...en nog soveel meer, is ' $n$ onloënbare bevestiging van die klaarblyklike sinloosheid van die menslike bestaan en die waarom van hierdie geteisterde lewe, groei by baie mense uit tot ' $n$ onontwykbare konklusie: daarom kan God nie goed wees nie, daarom kan Hy nie aan die beheer van alles wees nie, ja daarom kan Hy nie bestaan nie!” (Heyns 1978:144).

En inderdaad: as ' $n$ mens kyk na wat natuurrampe aan die mensdom - en dus ook aan die individu - doen, is dit sonder die lig van God se openbaring eintlik onmoontlik om dit met sy voorsienigheid te versoen. Die omvang daarvan is, trouens geweldig. Ses jaar gelede het die Verenigde Nasies se International Strategy for Disaster Reduction nie minder nie as 17 verskillende vorme van natuurrampe onderskei: sneeustorms en sneeustortings, droogtes, aardbewings, epidemies, hongersnode, vloede, bosbrande, haelstorms, hittegolwe, orkane, ysstorms, lawavloei, grond- en modderstortings, sinkgate, tornados en tsunami's. Afgesien daarvan was daar in die lang geskiedenis van die aarde ook enkele uiterste groot katastrofes soos ystydperke, reuse meteoriete wat die aarde getref het, sonuit-

3 Met vergunning van die betrokke redakteur is daar ten opsigte van bepaalde aspekte van die onderwerp in hierdie referaat ruim gebruik gemaak van die skrywer se artikel, Calvyn oor natuurrampe Acta Theologica (26/1), 2006, 112-133. 
barstings, sogenaamde supervulkane soos die uitbarsting by die Tobameer 75000 jaar gelede wat 'n groot deel van alle lewe op aarde uitgewis het, en megatsunamis soos ' $n$ golf van 85 meter hoog by die Ishigaki-eiland van Japan in April 1771. Die impak hiervan was soms geweldig. Daar word bereken dat die Spaanse griepepidemie van 1918 verantwoordelik was vir die dood van tussen 25 en 40 miljoen mense en dat die pes van die $14 \mathrm{e}$ eeu ' $\mathrm{n}$ derde van Europa se bevolking uitgewis het ${ }^{4}$. Die tsunami van 2004 het ' $n$ dodetal van meer as 200000 gehad, terwyl ' $n$ verdere twee en ' $n$ half miljoen mense daardeur rampspoedig getref is. Net in 2005 het 56 miljoen mense gely onder windstorms, 74 miljoen as gevolg van vloedwaters, 22 miljoen onder droogtes. Dit is presies sulke dinge wat mense soms laat vra: waar is God met sy voorsienigheid dan? ${ }^{5}$

Heyns was dit ook eens met talle ander toonaangewende teoloë dat dit nie binne menslike grense val om die diepte van God se voorsienigheid te peil of te verstaan nie. Na aanleiding van die destydse polemiek oor die regering van God skryf hy in 1992 in Die Kerkbode:

Om te verstaan dát God regeer en hóé Hy regeer, kan niks anders as maar net ' $n$ poging wees om iets daarvan te verstaan nie, want Hy is so groot en so gans anders as die mens (Heyns 1992:4).

Om vanuit bloot menslike gesigspunt te vra na die sin van die katastrofale, lei tot niks. Soos Berkouwer tereg opmerk, staan die sin van die lewe self in die katastrofe op die spel (Berkouwer 1950:23). En net so sê Van de Beek ook dat hy voluit oortuig is van die mens se onvermoë om die geheimenis van die skepping - en per implikasie dus ook van die voortgang daarvan in God se voorsienigheid - te deurgrond (Van de Beek 1996:248).

\section{VOORSIENIGHEID}

Die handelende teenwoordigheid van God vanuit sy kosmiesomvattende mag word feitlik deurgaans in Christelike denke tuisgebring onder die term voorsienigheid. Dit word, trouens, in talle belydenisskrifte van die kerke pertinent so uitgedruk. Die formulering van die Heidelbergse Kategismus is oorbekend: Dit is die

$\begin{array}{ll}4 & \text { Vgl. http://en.wikipedia.org/wiki/Natural_disaster } \\ 5 & \text { Vgl. www.unisdr.org en www.cred.be en www.em-dat.net }\end{array}$ 
almagtige en oral teenwoordige krag waardeur God hemel en aarde en al die skepsels asof met sy hand nog onderhou en regeer ... (HK So 10). In die Westminster Confession of Faith (1646) word dit so gestel: "God, the great Creator of all things, doth uphold, direct, dispose, and govern all creatures, actions and things, from the greatest even to the least, by his most wise and holy providence according to his infallible foreknowledge and the free and immutable counsel of his own will ..." (Westm Conf V, 1). Die Kategismus van die Katolieke Kerk sê: Ons noem die beskikkinge waarmee God sy skepping na volmaaktheid lei, goddelike voorsienigheid (KKK 302); die goddelike voorsienigheid bestaan uit die beskikkinge waardeur God met wysheid en liefde al die skepsels na hulle uiteindelike doel lei (KKK 321).

Talle teoloë, soos byvoorbeeld Johan Heyns, sluit hulle sonder meer by sulke uitsprake aan. Hy wys met nadruk daarop dat God sy skepping so bestuur dat hy sy doel daarmee bereik. "Nooit ooit verloor Hy beheer oor die gebeure in die wêreld of skort Hy sy beheer tydelik op nie" (Heyns 1992:4). Aan die anderkant is daar baie hedendaagse teoloë wat nie meer die klassieke leer van God as die grond van alles aanvaar nie en God - soos Van de Beek dit stel sekularisties uitskuif na die buiterand (Van de Beek 2002:184). So sien Wiersinga af van die tradisionele voorsienigheidsleer en praat eerder van "de sympathiserende God", klaarblyklik in aansluiting by wat Berkhof die "weerloze overmacht" van God noem (Wiersinga 1975:49 vv; Berkhof 1973:136 vv). In sy afwysing van Wiersinga se siening dat God aan die verandering van die wêreld werk, dat Hy deur sy meegevoel met ons die oorhand sal kry, en ons so in staat stel om die lyding te verdra, sê Van Genderen tereg dat ons die geloof dat God regeer, nie mag vervang met die gedagte dat Hy met ons simpatiseer en as bondgenoot aan ons kant staan nie (Van Genderen en Velema 1992:270).

Johannes Calvyn het sekerlik nie probeer om die voorsienigheid van God te verklaar nie. By die lees van sy geskrifte kom ' $n$ mens telkens onder die indruk van sy groot ontsag vir die voorsienigheid van God. Terselfdertyd blyk egter ook sy oortuiging dat die mens moet weet dat hy die diepte van God se handelinge nooit kan deurgrond nie. Die gedagtes van God waarin sy voorsienigheid setel, is enersyds nie net verborge (arcanus) vir menslike denke nie (vgl Potgieter 2002:102 vv), maar dit is ook die beslissende en aktiverende faktor in die geskiedenis (Saxer 1980:22). Selfs na meer 
as vier eeue is dit na my mening nog oor en oor die moeite werd om deeglik kennis te neem van wat Calvyn vir ons nagelaat het.

Die voorsienigheidsleer was nie in die eerste plek vir Calvyn ' $n$ leerstellige saak is nie. Dit is veel eerder ' $n$ bepaalde grondmotief waardeur die eer van God as uiteindelike doel van alles wat in die lewe van dag tot dag gebeur, aangedui word (Saxer 1980:22). Daarom ook sy vertroostende woord aan medegelowiges wat onder teenspoed gebuk gaan "dat hulle geen lyding ondergaan nie behalwe as God dit verorden en beveel omdat hulle onder sy hand is" (Inst 1,16,3; OS, 190).

In teologiese kringe het hierdie beskouing van die Geneefse hervormer meermale ernstige kritiek ontlok. Alhoewel König nie pertinent aandag gee aan Calvyn se siening oor natuurrampe nie, reageer hy breedvoerig op die hervormer se voorsienigheidsleer oor die algemeen, en beskou dit as "een groot apologie vir die albeskikking van God”.

Daarmee wil hy (Calvyn) beklemtoon dat God alles vooraf bepaal het, dat niks sonder sy beskikking gebeur nie, en dat Hy in geen opsig sy voorafbepaalde plan verander nie (König 2001:192).

Hierdie benadering sien König klaarblyklik as besonder onbevredigend, en een waarvan die noodwendige konsekwensie is dat God outeur van die kwaad moet wees. Hy meen dat teoloë - onder andere Calvyn - in die verlede die vraag na God se voorsienigheid probeer beantwoord het "voordat hulle oor die sonde en ellende nagedink het” (König 2002:196).

"Toe moes hulle agterna verleentheidsoplossings probeer kry vir onoorkomelike probleme. Verder het [sulke teoloë] hulle uitgangspunt in God se almag geneem, en daardeur sy liefde in die gedrang gebring” (König 2002:197).

In verband met die kwaad as verskynsel doen König gevolglik aan die hand dat God die kwaad volgens Calvyn vooraf beskik het omdat Hy deur die kwaad 'n goeie doel wil bereik (König 2001:193). Ek meen egter dat so ' $n$ siening nie die konteks van sy uitsprake genoegsaam verreken nie en dus nie ten volle reg laat geskied aan die oortuiging van die Geneefse hervormer nie.

Waar König oor die voorsienigheid handel, stel hy dit as sy oortuiging dat die tradisionele siening van die almag van God nie 
Bybels verantwoordbaar is nie. Hy meen dat die uitsprake in die Heilige Skrif dat niks vir God onmoontlik is nie, nie gesien moet word as algemene uitsprake oor enige saak nie, en nie beteken "dat God te eniger tyd enigiets kan doen nie. Dit is spesifiek gerig op die vervulling van sy beloftes. In hierdie sin beteken God se mag nie dat Hy enigiets te eniger tyd kan doen nie, maar dat Hy kan doen wat Hy beloof het” (König 2002:213). “Ons het Hom immers leer ken as die God wat wel nie altyd so maklik en so gou regkry wat Hy graag wil nie, maar wat aanhou tot Hy sy doel bereik en sy beloftes vervul het” (König 2002:237).

In die debat wat in die vroeë negentigerjare in die kerklike pers oor God se beheer oor sy skepping gevoer is, sê Johan Heyns kategories:

"Maar ek weet ook ek is nie uitgelewer aan blinde en redelose magte, of aan 'n God wat moet stry om weer beheer oor sy skepping te verower nie. God regeer. Hy sal nie eers eenmaal regeer nie. Hy regeer nou" (Heyns 1992:4).

Die keuse waarvoor ons klaarblyklik volgens König staan is òf dat God enige oomblik enigiets kan doen - maar dan gee Hy nie om dat mense daagliks so vreeslik en sinloos ly nie - òf dat God radikaal daarteen is dat daar soveel sinlose lyding op aarde is, maar Hy kan nie enige oomblik enigiets doen wat Hy graag wil nie. Ek meen dat dit 'n oorvereenvoudiging van die saak is.

Calvyn verwys in verskeie van sy geskrifte - leerstellig sowel as meer populêr - na rampspoedige gebeure buite die mens se beheer. Die rampspoed wat mense soms in sy tyd getref het - hetsy by wyse van siekte, verlies of ook deur natuurrampe - het hom aan die hart gegryp. Daarom wil hy gelowiges ook in die lig van die Heilige Skrif begelei op die soms moeilike weg van die aanvaarding van God se voorsienigheidshandelinge. Sy pastorale empatie blyk, trouens, onder meer uit die wyse waarop hy herhaaldelik in sy briewe uitreik na mense wat deur een of ander ramp getref is (Potgieter 1991:85). Dit is merkwaardig hoe hy meermale gepoog het om sulke gebeure vanuit sy geloof in die voorsienigheid van God te verduidelik en selfs te regverdig.

Dit is egter ook weer ongetwyfeld so dat die voorsienigheidsleer vir hom nie soseer ' $n$ saak van verduideliking was nie, maar eerder een van belydenis. Na aanleiding van rampspoedige 
gebeure in Geneve, skryf hy op 1 Oktober 1538 aan die kerk daar dat hulle moet weet dat sulke dinge nie buite die voorsienigheid van God plaasgevind het nie (CO 10, 251). Die voorsienigheidsleer vra derhalwe eerder belydenis as begrip. Toegang daartoe lê op ' $n$ geloofsvlak, eerder as op dié van rasionele insigte (vgl Reuter 1963:171). Calvyn se hele teologie berus, trouens, inderwaarheid op ' $n$ diep oortuiging in die hart en geloof in God se omvattende heerskappy oor die volle omvang van sy skepping (Potgieter 2002:102).

Calvyn soek nie na ' $\mathrm{n}$ verklaring van God se voorsienigheid nie, maar hy bely met oorgawe God se alles-omvattende greep op die geskape werklikheid. Dit is ongetwyfeld so dat hy tradisioneel dink oor enige rampspoed wat op die mens se pad mag kom. Al ontkom die gelowige ook nie daaraan nie, kan hy dit aanvaar binne ' $\mathrm{n}$ wyer bybelse en Christologiese konteks: die lyding van Christus is trouens die grondliggende werklikheid van gelowige en gehoorsame bestaan (Schreiner 1994:95).

Maar ook in die Genéve van Calvyn het gelowiges - net soos in ons dag - soms moeite gehad het om die voorsienigheid van God met sy regverdigheid in verband te bring. Veral met sy preke uit die boek Job het Calvyn vir hulle probeer aantoon dat hulle maar net kon erken en bely dat hulle die geregtigheid van God nou nog nie kan sien nie, maar dat hulle eendag die voorsienigheid van God sal sien soos dit werklik is (vgl Schreiner 1986:175 v).

As jy oplet, sal jy maklik opmerk (facile perspicies) dat dit die toppunt van alle ellende is om nie die voorsienigheid van God te ken nie, maar dat daar die hoogste geluk in die kennis daarvan aanwesig is (Inst 1.17.11 vert van Simpson; OS III, 216).

Daar was vir Calvyn geen twyfel nie dat daar binne die voorsienigheid van God geen ruimte vir toeval of noodlot is nie. Daarvoor beroep hy hom onvoorwaardelik op die Heilige Skrif. So stel hy dit pertinent in die inleiding tot sy kommentaar op Psalm 107 dat die Bybel duidelik genoeg leer dat wat met die mens gebeur, nie bepaal word deur ' $n$ wispelturige en onsekere noodlot nie, maar dat ons die oordele van God moet waarneem in die verskillende wederwaardighede (in variis agitationibus) wat in die wêreld voorkom, en waarvan mense soms dink dat dit per toeval gebeur. Waar Psalm 105:16 sê dat God "hongersnood oor die land gebring het", is 
dit asof dit reeds gereed was en net gewag het op sy bevel. Daaruit kan ons aflei dat hongersnood, pessiektes en ander oordele van God die mens nie maar per toeval tref nie, maar dat dit in gehoorsaamheid aan God deur sy hand gestuur (Dei mani dirigi) word waarheen dit Hom behaag (Komm Ps 105:16; CO 32, 104). Gevolglik moet teëspoed en al die kwaad wat die mens moet verduur - skipbreuk, hongersnood, ballingskap en oorlogsrampe - gesien word as soveel tekens van God se ontevredenheid waardeur Hy hulle as gevolg van hulle sonde voor sy regterstoel daag (Komm Ps 107 Inleiding; CO 32, 135).

Farley vat dit goed saam:

What Calvin spells out so clearly for all to see is that it is not necessity or determination but divine guidance that lies at the heart of a biblical and Reformed understanding of God's providential overruling (Farley 1988:156).

Hieroor moet daar dus by die gelowige geen twyfel wees nie. Onder geen omstandighede moet gedink word dat rampe toevallig op ons pad kom nie.

Die reël van godsvrug is daarenteen dat God se hand alleen die (mens se) lot lei en regeer en dat die lot nie self met 'n ondeurdagte stormloop aanstorm nie maar dat God se hand met die ordelikste geregtigheid goed sowel as kwaad vir ons beskik (bona simul ac mala dispensare, Inst 3.7.10; OS IV 161).

Die albestier van God in die geheel van die kosmos is ' $n$ beginsel wat Calvyn konsekwent handhaaf. Daarom sê hy onomwonde dat "die voorsienigheid van God soos dit in die Skrif geleer word, teenoor die noodlot en toevallige gebeure gestel word" (Inst 1.16.2).

Hierdie konsekwente afwysing van elke vorm van toeval word egter nie deur alle teoloë gesteun nie. In sy analise van Thomas Aquinas se kousaliteitsdenke kom Van de Beek byvoorbeeld tot die gevolgtrekking dat Thomas God wel betrokke sien by elke gebeure. Maar omdat daar ' $n$ kategoriese verskil tussen God as eerste oorsaak en die tweede oorsake van die geskape wêreld is, kan daar op die vlak van tweede oorsake tog van toevallighede gepraat word (Van de Beek 2002:171). Hendricus Berkhof laat ook 'n versigtige opening daarvoor as hy sê dat die speelruimte van die skepping so groot is, dat toeval en noodlot ook daarin werklikhede is, "wel niet zo dat ze 
het laatste woord hebben, maar wel al elementen binnen een geheel dat uiteindelijk niet uit de hand van God valt” (Berkhof 1973:231). Van de Beek meen selfs dat Karl Barth se model van unhistorische Geshichte 'n deïstiese tendens toon, waar hy God se skeppingshandelinge as eerste oorsaak van alles sien, maar tog wil hê dat Hy nie die oorsaak van elke gebeurtenis is nie (Van de Beek 2002:182).

Ek meen dat Paul Helm in sy werk oor die voorsienigheid van God ' $n$ verhelderende opmerking in dié verband maak as hy sê dat toeval (chance) maar net 'n woord is wat uitdrukking gee aan ons onkunde.

It represents our ignorance of causal factors, perhaps our necessary ignorance. It is not a word for some agent of chaos or meaninglessness, which is set over against God (Helm 1994:144).

Ons vind dieselfde benadering, trouens, ook reeds by Calvyn as hy sê dat rampspoedige gebeure soms vir ons toevallig kan lyk (OS III, 200), maar dat dit tog deur God beskik is (Inst 1.16.5). Wat Calvyn hiermee duidelik genoeg stel, is dat ons nie die fout moet maak om op grond van ons gebrekkige insig tot die gevolgtrekking te kom, dat gebeure bepaal word deur die toeval, en nie onder God se voorsienige bestiering nie.

In sy afwysing van die fatalisme sê Johan Heyns ook Gods regering beteken dat Hy mag het om te doen wat Hy goed vind om te doen en dat Hy die werke van sy hande nooit aan die toeval of geluk oorgee nie (Heyns 1992:4).

\section{GOD, KOSMOS EN GESKIEDENIS}

Dat God as Skepper ' $n$ bepaalde orde - onderhewig aan kosmiese wetmatighede - daargestel het, kan uit teologiese gesigspunt nie bevraagteken word nie, en net so min dat dit ' $n$ bepalende faktor in die verloop van die geskiedenis is. Die gang van dié orde - sê Van de Beek - kan net op die Woord van die Here self deurbreek word (Van de Beek 1996:249).

In ooreenstemming met sy leer oor die algemene openbaring meen Calvyn dat daar tog in elke mens van nature iets deurskemer van hoe God volledig gesag voer oor die ganse kosmos. Daarom sê hy ook dat daar maar net een manier is waarop ' $n$ Christen oor hierdie dinge moet dink. Dit is tog 
in ons harte ingeprent dat niks sal gebeur wat God nie voorsien het nie. In hierdie sin word die woord lot (eventus) telkens in (die boek) Prediker gebruik. Die rede is dat die mens nie met sy eerste ondersoek (primo intuitu) daarvan kan deurdring tot die eerste oorsaak (OS III, 200), wat ver verborge is nie (OS III, 200). En tog was die openbaring van die Skrif in verband met die verborge voorsienigheid van God nooit so in die harte van mense uitgewis dat daar tog nie iets van 'n vonkie in die duisternis geglinster het nie (Inst 1.16.9).

Calvyn is nogal versigtig met die gebruik van die begrip toelating van gebeure in die Institusie. In sy preke gebruik hy dit klaarblyklik met groter vrymoedigheid (vgl Stauffer 1978:276 v). Dit is egter baie duidelik ' $n$ doelbewuste en geen passiewe toelating nie (Van Genderen \& Velema 1992:289). Calvyn wou rampe en ellende dus beslis nie maar toeskryf aan die blote toelating van God nie; dit het ook êrens 'n plek in sy wil, maar dan op 'n manier wat vir ons verborge bly (Inst I.18.1).

God is op ' $n$ aktiewe en deurlopende wyse werksaam in die geskiedenis van die wêreld; vir Calvyn is die gedagte van blote toelating van gebeure by God geheel en al onhoudbaar (Inst 1.18.1). Hy verwerp ook elke idee van ' $n$ deïstiese benadering, net asof Hy alle dinge sou toelaat om met 'n vrye loop volgens die ewige wet van die natuur te verloop. Niks sou ellendiger as die mens gewees het as hy "aan elke beweging (motus) van die hemel, die lug, die aarde en water (sic!) blootgestel sou wees nie" (Inst 1.16.3; OS III, 191). Hy toon, trouens, met voorbeelde aan hoe onhoudbaar so ' $n$ siening sou wees. Indien ons sou toegee dat God net alles in beweging gestel het, maar dat alles dan spontaan of toevallig sou voortgaan in die rigting wat eie is aan hulle natuur

dan sou die wisseling van dag en nag, van winter en van somer God se werk wees ... maar dat onmatige hitte gepaard met droogte soms al die oeste verskroei en dat by ander geleenthede weer ontydige reën die oes bederf en dat daar onverwagte rampe as gevolg van hael en donderstorms voorval - dit sal nie God se werk wees nie ... so word daar geen plek gelaat vir God se vaderlike guns of sy oordele nie (Inst 1.16.5; OS III, 195). 
König sien dit egter anders. Wanneer hy sê dat die enigste ware God teenstand ondervind teen sy oogmerke; weerstand deur bose magte; ontrou van sy kinders; voortdurende oortredings van sy wet en verontagsaming van sy gesag (König 2002:221), is dit natuurlik waar. Maar hy gaan verder: van die aaklige dinge wat die duiwel en mense beplan en doen, sê hy in soveel woorde "God kry nie altyd reg om dit te keer nie” (König 2002:234). Dit sluit aan by sy afwysing van die idee van die almag van God. Hy handhaaf wel die "geweldige groot mag van God, maar nie van almag in die populêre filosofiese sin van die woord nie” (König 2002:210). Hy grond dié siening veral daarop dat hy in die Ou Testamentiese Hebreeus geen woord vind wat God se almag aandui nie, en dat die Griekse pantokrator wat meermale in die boek Openbaring voorkom, bloot aan ' $n$ foutiewe vertaling in die Septuagint ontleen is. Daarom meen hy dat daar in die verlede te veel op die harde mag van God gekonsentreer is, maar dat sy uniekheid eerder lê in die vorms van sy sagte mag: sy oorredende mag, sy lydende mag, sy helende mag (König 2002:227).

Hiermee kom König na my gevoel in die omgewing van Berkhof wat klaarblyklik ook die almag van God hier en nou relativeer wanneer Berkhof sê dat daar nie so iets soos ' $n$ harmoniese verhouding tussen die liefde van God en die wêreldgebeure bestaan nie, en dat God hom in 'n worsteling met en om hierdie wêreld bevind (Berkhof 1973:223, 225).

Vir Calvyn is God egter volledig in beheer van sy skepping. God is by magte om die kragte van die natuur te gebruik om sy wil te doen en doen dit ook inderdaad soms, soos wanneer Hy deur die oostewind sprinkane as plaag oor Egipte bring. Hy sê: op ' $n$ Goddelike wyse is hulle deur die krag van die oostewind aangebring (OC 24, 124). In sy bestiering van die kosmos kan Hy dus natuurkragte gebruik as middele om sy doel te bereik. Hy kan egter ook heeltemal sonder die gebruik van middele optree, of selfs op 'n wyse wat in teenstelling tot natuurlike middele staan (OS III, 202).

Calvyn verwys soms nogal na spesifieke natuurgebeure wat onder die gesag van God verwerklik word. So sê hy dat geen wind ooit opkom of gaan lê sonder dat God dit in besonder beveel nie (OS III, 197). "God gebied en verwek die geblaas van 'n storm en Hy hef die golwe van die see omhoog” (OS III, 197). Op verskeie plekke in sy kommentare stel Calvyn dat God die mag van water in sy hand het. Hy sien dit as een van die wonders van God dat Hy die mag van 
die see, asof met grense, in toom hou sodat dit nie dié deel van die aarde wat vir die mens se bewoning gegee is, oorweldig nie. Deur sy verborge krag (arcana eius virtute) sorg God dat die onderaardse water nie oopbreek en ons oorweldig nie, en dat die water uit die hemel nie vir dieselfde doel daarmee saamsweer nie (Komm. Gen 7:11; OC 23, 131). In sy kommentaar op die geskiedenis van die stormwind en golwe wat deur Christus tot bedaring gebring is, sê hy dat dit die krag van sy stem was wat tot die elemente deurgedring het sodat hulle die bevel van God gehoorsaam het en dat dit ' $\mathrm{n}$ bewys was van sy Goddelike mag (Komm Mt 8:26, 27).

Calvyn lewer op verskillende plekke ook kommentaar op aardbewings waarvan die Bybel gewag maak. Soms het God dit laat gebeur as ' $n$ teken van sy mag soos in die geval van Paulus en Silas se verlossing uit die tronk in Filippi (Komm Hd 16:26; CO 48, 386), of wanneer Hy mense bewus wou maak van sy Goddelike krag soos by die opstanding van Jesus (Komm Mt 28:2; CO 45, 792). In ander gevalle, soos met die geweldige aardbewing in die tyd van Ussia, koning van Juda, was dit ' $n$ ontsagwekkende teken en voorbode (horribile signum, vel praesagium) van God se wraak. Hy het daarmee bedoel om ' $n$ vreeslike ramp oor die Jode aan te kondig (Komm Sag 14:5; CO 44, 366).

Dat sulke dinge gebeur, moet ook nie vir Christene vreemd wees nie. Deuteronomium 28 handel, trouens, van vers 15 af oor al die rampe - ook in die natuur - waarteen Moses die Israeliete gewaarsku het as hulle nie luister na die Here hulle God en nie gehoorsaam is aan al die gebooie en voorskrifte wat aan hulle voorgebou is nie. Hiervan sê Calvyn dat

alhoewel al hierdie onheile ' $n$ natuurlike oorsaak het, dit steeds God, die Outeur van die natuur, is wat die atmosfeer so beheer dat die nadele (intemperies) daarvan ongetwyfeld sy straf (eius flagellum) is (CO, 25, 32).

\section{NATTUURRAMPE - VANWAAR EN WAARTOE}

Vanuit menslike gesigspunt op die voorsienigheid kom daar ' $\mathrm{n}$ vanselfsprekende vraag na vore: is die oorsaak van natuurrampe by God? En vervolgens dan die noodwendige vraag: indien wel, is God dan ook verantwoordelik vir al die ellende wat dit vir die mens en die wêreld inhou? 
Oor die kwessie of rampe en teëspoed ook deur God gestuur word, laat Calvyn hom duidelik genoeg uit. Waar hy handel oor die oordeel van God oor die volke in die profesie van Jeremia, sê hy onomwonde dat daar twee dinge is wat onthou moet word:

dat geen teëspoed per toeval kom nie, maar dat God die outeur van al daardie dinge is wat mense as onheile sien; en dat Hy so is, omdat Hy ' $\mathrm{n}$ regverdige Regter is - dit is die tweede ding. God eis die beheer oor alle gebeure vir Homself op, en as hy sê dat die wêreld volgens sy wil beheer word, verklaar hy nie net dat alle mag en die opperste beheer in sy hand is nie; hy gaan verder en toon aan dat dinge wat gelukkig afloop die bewys is van sy goedheid en geregtigheid, en dat rampe die bewys is dat Hy die mens se sonde nie kan verduur nie, maar dit moet straf. Dit is presies wat die profeet wou uiteensit (Komm Jer 25:20; CO 38, 490).

'n Interessante gesigpunt word deur Ariane Arpels-Josiah na vore gebring. Alhoewel Calvyn die voortgesette integriteit van die natuurlike wêreld aanvaar, wil hy tog nie aan die natuur 'n te groot onafhanklikheid van God toeken nie.

This is most visible when Calvin underscores nature's need for God. Already inherently fragile at the creation, the nature of the cosmos became positively threatened with the fall. The danger of disorder, chaos, and collapse, so vivid in Calvin's view of cosmology and history, shaped his view of providence into one in which God powerfully restrains and stabilizes the created order (Arpels-Josiah 2004:149 v).

Die kosmos kan waardeer word as goeie skepping, maar tog gekwalifiseerd as voortdurend op die rand van chaos (Arpels-Josiah 2004:156). Dit is ongetwyfeld ' $n$ juiste interpretasie van Calvyn'. Waar Calvyn in sy kommentaar op Genesis 3:19 oor die gevolge van die sondeval handel, sê hy inderdaad uitdruklik dat al die ongerief (incommoda) waarin die mens homself deur sy sonde gedompel het, nie eers genoem word nie. Al die ontelbare manifestasies van die kwaad wat ons in die lewe ervaar, vloei voort uit dieselfde fontein.

$6 \quad$ Vgl. bv. Komm Gen 1:6; OC 23, 18; Gen 7:11; OC 23, 131; Ps 24:2; OC 21, 244; Ps 104:6; CO 32, 87; Ps 107:29 CO 32, 141 ens. 
Die guurheid van die weer, ryp, donderweer, ontydige reën, droogte, hael en al wat in die wêreld wanordelik is, is die vrug van die sondeval ... Die hele orde van die natuur is ondergrawe deur die mens se val (Komm Gen 3:19; CO 23, 75).

In sy kommentaar op Romeine 8:20 v skryf hy die rampspoed wat op aarde voorkom uitdruklik toe aan die sondeval en die straf op almal se sonde. "So is die veroordeling van die mensdom afge-ets op die hemele en op die aarde en op die hele skepping” (Komm Rom 8:20 v; CO 49, 152). Hy sê ook dat die wêreld voor die val die pragtige beeld van goddelike guns vertoon het (Komm Gen 3:17; CO 23, 73).

Ons weet egter dat daar talle teoloë is wat nie gemaklik is met so 'n benadering nie. Die kernvraag wat gestel word, is hoe die voorsienige sorg van God oor sy skepping versoen kan word met fisiese rampe, aardbewings, storms wat met geweld woed en virusse wat epidemies en tallose sterftes veroorsaak. Hoe kan die bestaan van 'n almagtige, algoeie God versoen word met die bestaan van fisiese rampe? (vgl Helm 1994:24 v). Vir Berkhof is die siening dat natuurrampe die gevolg van die sondeval is, totaal onhoudbaar, omdat "strijd, lijding, dood en natuurcatastrofes al miljoene jaren vóór het verschijnen van die mens hun intrede hadden gedaan". Daarmee erken ons - sê hy - dat daar " $n$ tragiese element in die wêreld is. Dit is onvoltooid, onaf, defektief. "Er is veel verdriet waarvan niemand de schuld draagt” (Berkhof 1973:178 v). Hierdie siening - wat trouens deur verskeie teoloë gehandhaaf word - bring ons myns insiens vlak by die erkenning van ' $n$ oerdualisme, en gevolglik ook by die vraag na die oorsprong van dié bose kragte "waarteen God moet stry om sy oogmerke te bereik" (König 2002:219). Ek kom later terug op Berkhof se beswaar in verband met natuurrampe lank voor die sondeval.

Vir Calvyn was daar egter geen twyfel oor die verband tussen die mensdom se sondigheid en katastrofale gebeure nie. In sy traktaat oor Die noodsaaklikheid van Kerkhervorming wys hy onder andere op die gruwel van afgodery en hoedat die geskiedenis ons meermale vertel van die vreeslike straf waarmee God mense hieroor besoek het - deur die swaard, siekte-epidemies, hongersnood en elke denkbare ramp (Calvyn 1998a:248). 
Rampspoed tref dus nie net die goddelose en ander wat moedswillig in die sonde volhard nie. In sy Vierde Preek oor Pinkster sê Calvyn dat die Here se waarskuwing in Handelinge 2:18-21 ook tot ons gerig is. Ons moet nie te gerus wees en dink dat ons sal ontkom aan oorloë, hongersnode en pessiektes nie. As sulke rampe op ons pad kom, moet ons dit geduldig dra en dit nie vreemd vind nie, want die oorsaak is die ondankbaarheid wat in ons is. "Dit is soos ons die oordele (les iugemens) van God moet bedink" (CO 48, 651).

Sy siening hieroor word verder geïllustreer in sy korrespondensie. 'n Ernstige epidemie van pes het in 1542 in Genéve uitgebreek. Klaarblyklik het Calvyn 'n brief van ene Monsieur le Cure de Cernex ontvang waarin dié argumenteer dat die plaag daar sonder twyfel ' $n$ oordeel van God is. Hierop antwoord Calvyn dan in ' $n$ ongedateerde brief ${ }^{7}$ dat hy daarmee saamstem en bely dat hulle regverdiglik gestraf word omrede hulle foute en tekortkominge (faultes et demerites) (CO 11, 483). Hy sê ook dat ons soms wonder hoe dit gebeur dat daar soveel oorloë, soveel pessiektes, soveel misoeste, soveel rampe en soveel ellendes is. "Asof die oorsaak nie duidelik is nie! Ons moet ook nie ' $n$ einde aan ons ellendes verwag voordat ons die oorsake daarvan verwyder het deur ons gebreke (vitia nostra) reg te stel nie” (Komm 1 Kor 11:30; CO49, 494).

' $n$ Interessante opmerking van Calvyn gaan oor ' $n$ algemene aanvoeling van alle mense oor die oorsaak van rampe. Daar is, trouens, reeds verwys na die Institusie waar hy sê dat daar in elke mens van nature iets deurskemer van hoe God volledig gesag voer oor die ganse kosmos. In sy kommentaar op Handelinge kom hy hierop terug en betrek dit dan ook op rampspoed wat die gevolg van sonde is:

Met die oogmerk om die wêreld sonder verskoning te stel, wou God hê dat dit diep by almal ingewortel moes wees dat rampe en teëspoed - en dan veral dinge wat duidelik-waarneembare verwoesting inhou - bewyse en tekens van sy toorn en regverdige oordeel oor sonde is. Ons moet dus telkens as ons aan 'n kennelike ramp dink, ook onthou dat God diep gekrenk is en daarom so swaar straf. (Komm Hd 28:4; CO 48, 560).

7 Algemeen word aanvaar dat die brief uit laat 1542 of vroeg 1543 dateer. 
Hierdie siening van Calvyn vind nog steeds steun in die gereformeerde wêreld. Die mens het alles in sy val meegesleur. Daarom is die skepping nie meer soos dit was toe God dit daargestel het nie. "De disharmonie is door ons veroorzaakt" (Van Genderen en Velema 1992:287). Maar in die onruswekkende wanorde - sê Heyns - is daar tog wel 'n vaste orde en is daar vir ons die troos dat die hand van God in alles en oor alles is, al is sy hand nie agter alles in die sin dat Hy alles veroorsaak nie (Heyns 1992:4).

\section{NATUURRAMPE EN GELOOF}

Die deurslaggewende vraag is of geloof in die God en Vader van ons Here Jesus Christus 'n verskil maak wanneer dit kom by die benadering tot natuurrampe. Enersyds is daar teoloë wat meen dat gelowiges sulke gebeure soms op ' $n$ byna naïewe wyse aanvaar. Berkhof sê byvoorbeeld dat dit vir baie mense is asof hulle hele geloof opgaan in die oortuiging dat "we allen in Gods hand zijn" (Berkhof 1973:224 v). Daarteenoor sê Heyns weer dat die gelowige nooit en nêrens weerloos en oorgegee is aan dreigende magte in die natuur of in die geskiedenis nie. "Daarom kan die gelowige deur die natuurlike gebeure heenkyk en God self daaragter en daarbo ontdek" (Heyns 1988:160 v).

Ek hoor Calvyn ook sê 'n gelowige moenie "tot misnoë van God oor sy lot kla nie, wat ookal met hom gebeur” (OS IV, 160). Onder die dinge waardeur ' $\mathrm{n}$ mens soms geteister kan word, noem hy ook natuurrampe: ryp of hael wat ons jaar se verwagting verteer. Selfs as hy sien dat hongersnood dreig omdat sy gesaaides deur ryp verdor is, of deur koue verteer of deur hael platgeslaan is, sal sy gemoed nogtans nie wanhoop en God se misnoë verwek nie (OS IV, 160). Daarom het hy ook sy mede-gelowiges opgeroep tot gebed en vas in tye van beproewing en rampe. Hy sien vas, trouens, as ' $n$ heilige oefening om mense ootmoedig te mak sowel as om hulle ootmoed te bely wat in ' $\mathrm{n}$ noodtoestand tans niks minder toepaslik is as wat dit in Ou Testamentiese tye die geval met die "Israelitiese kerk” was nie (Inst 4.12.17; OS V, 227).

Wat dus essensieel is in die mens se toenadering tot God onder sulke omstandighede is ootmoed en hartgrondige belydenis. In ' $\mathrm{n}$ brief aan Bucer (15 Oktober 1541) sê Calvyn dat daar by 'n epidemie van pes (waaroor die mens dus nie beheer het nie) maar net een opsie oorbly, naamlik om ons toevlug te neem tot gebed waarin 
ons voor God kom met berou en sondebelydenis - iets waarin ons maar al te agtelosig is (CO 11, 297).

Calvyn maak steeds op ' $\mathrm{n}$ merkwaardige wyse die voorsienigheid van God van toepassing waar hy handel met mense wat vertroosting nodig het. Hy wou graag hoop en vertroosting aan gelowiges oordra deur nadruk te lê op die voorsienige hand van God oor hulle lewens. Verwysing na die voorsienigheid van God kry veral in sy briewe as't ware 'n terapeutiese oogmerk. Daarmee wou hy juis wegbreek van die tipies middeleeuse idee van ' $n$ blinde noodlot, wat hy vanselfsprekend onomwonde verwerp het (Potgieter 1991:93 v). So skryf hy onder andere dat aanvaarding en berusting in die voorsienigheid van God behoort by die diens van die Here; dit moet selfs die geval wees as ons nog nie die laste wat ons kwel, verstaan nie (CO 20, epist 3947).

Sy diep gelowige benadering tot ramspoed blyk ook telkens uit sy prediking. Wanneer hy preek oor die boek Job, lê hy nie net nadruk op die kwalitatiewe van God se gawes nie, maar ook op die kwantitatiewe. Hy gebruik telkens woorde soos bereken (CO 33-35, sermon $\mathrm{x}$ ) of tel (CO 33-35, sermon $\mathrm{x}$ ) in die verband. Daarmee wil hy sê dat die weldade van God altyd meer is as die teëspoed wat ons ervaar.

God doen soveel goed aan ons; sal ons dan nie die slegte ook van Hom aanneem wanneer Hy dit so wil nie...Die genade van God is ontelbaar en onbegryplik. Waarom sal ons dan nie ook die teenspoed aanneem wat Hy oor ons beskik nie? En selfs as die aanvegtinge veel meer word, gaan sy weldade nog ver uit bo die teenspoed wat ons uit sy hand moet ly (Preek Job 2:10; CO 33, 115 vv).

Calvyn se pastorale hart blyk nie net uit sy briewe en preke nie, maar ook uit sy kommentare wat per slot van rekening gerig was op die gewone kerkvolk wat hulle deel aan swaarkry en teëspoed geken het. Daarom vind hy ook ' $n$ besondere trooswoord in 2 Korintiërs 4:11: Voortdurend word ons wat lewe, ter wille van Jesus uitgelewer aan die dood, sodat ook in ons sterflike bestaan die lewe van Jesus sigbaar kan word.

Hy sê dat ons hierin die beste teenmiddel vir rampspoed het, naamlik 
dat net soos ons weet dat Christus se dood die poort tot die lewe is, weet ons ook dat 'n geseënde opstanding vir ons die einde van alle verdriet sal wees, want Christus het Hom met ons geassosieer onder die voorwaarde dat ons deelgenote van sy lewe sal wees as ons bereid is om in hierdie wêreld met Hom te sterwe (Komm 2 Kor 4:11; CO 50, 55).

Dit is trouens ' $n$ egte en onbetwyfelbare bewys van ons geloof wanneer ons ten spyte van teëspoed wat ons tref, nogtans volhard in die koestering van hoop op God (Komm Ps 7:4; CO 31, 80).

Berkouwer is volkome reg as hy sê dat die probleem van die teodisee onoplosbaar is buite die geloof om - maar dan ook ' $n$ geloof wat sy grense ken. In die lig van die openbaring is die rus van die geloof in God se heilige wêreldbestuur maar net moontlik vanuit die erkenning van skuld. "En in deze belijdenis, is het mogelijk God te eren in Zijn ondoorgrondelijk bestel, waarin Hij de wereld regeert" (Berkouwer 1950:318). Oor insig in God se voorsienigheid sê Hans Küng dat dit net agterna is dat jy kan sien wat die dieper betekenis van die begin af was. "Ek kan God nie van voor af sien nie, en hoef ook nie. Hy is te groot vir my om in staat te wees om sulke eise aan Hom te stel. Deus semper maior. Hy is die altyd groter God” (Küng 1980:654).

\section{MET WATTER DOEL?}

In my ondersoek was dit opvallend dat daar klaarblyklik 'n huiwering by teoloë is om hulle te waag aan God se doel met groot natuurrampe in die wêreld. By Johannes Calvyn was daar hieroor egter geen twyfel hoegenaamd nie. Sy siening dat God mense tot inkeer wil bring deur hulle met rampe en ellendes te teister, blyk reeds duidelik uit sy Gebed vir die Oggenddiens op die dag van die Here, waar hy erken dat sulke dinge die roede is waardeur God sy kinders tot die regte weg terugbring. (CO 6, 177).

Hy verwys ook by geleentheid spesifiek na die effek wat 'n skrikwekkende natuurverskynsel op mense behoort te hê. $\mathrm{Na}$ aanleiding van Jesaja 2:21 (As die Here die aarde begin skud, sal hulle die rotsholtes en die klipskeure invlug ...) oordeel Calvyn dat sulke tekens nodig is om die mens tot besinning te bring. "Want wat is so moeilik as om mense " $\mathrm{n}$ ware vrees van God op die hart te bind?" Dit is veral nodig dat so 'n oordeel van God met erns voor die skynheiliges gestel word (Comm ad loc; CO 36, 76). Mense is 
dikwels geneig om rampspoed van enige aard bloot te sien as ' $n$ veroordelende bestraffing van God. Calvyn wil daarin eerder ook ' $n$ genadige handeling sien.

In sy kommentaar op Lukas 21:8 waar onder meer ook na aardbewings verwys word, sê Calvyn dat gelowiges moet weet dat daar soms ' $n$ langdurige oefening in geduld sal wees (CO 45, 652). In die Institusie sê hy ook êrens dat God dikwels die wat aan Hom behoort op die proef stel met ruwe toetse (asperis documentis) - net asof Hy hulle geloof doelbewus wil uitdoof (Inst 3.20.16; OS IV, 321). Al noem hy dit daar in ' $n$ ander konteks, bly dieselfde beginsel van krag.

Hy wil dus benadruk dat God ons nie verniet laat swaarkry nie. Ons moet sy oordele sien as 'n middel waardeur Hy ons tot groter gehoorsaamheid wil bring. En selfs as dit by herhaling gebeur, is dit nodig omdat ons sondige natuur telkens weer na vore kom. Iets hiervan vind ek ook by Berkouwer wat wou dat die duidelike prediking van die verband wat God self gelê het tussen sonde en gerig teenoor elke poging tot verontskuldiging moet staan. "Het is God, die de mens doet wederkeren tot verbrijzeling" (Berkouwer 1950:314).

\section{GOD SE VERBORGE PLAN}

Die oortuiging van Calvyn waardeur hy letterlik alles wat in die geskiedenis gebeur onder die beskikking van God plaas, is dikwels bevraagteken en gekritiseer. Enersyds is daar die probleem dat ons dikwels nie die geregtigheid en liefde van God kan versoen met rampspoedige gebeurtenisse en die lyding en smart wat dit vir mense - ja ook vir diep gelowige mense - meebring nie. Andersyds is daar ook die vraag na die oënskynlik-noodwendige konsekwensie van Calvyn se siening, naamlik dat God die oorsaak van rampe en die kwaad in geheel moet wees.

Teoloë het soms die sleutel tot oplossing van sulke probleme gesoek in die rigting van Calvyn se hantering van die verborge Raad van God. Dit is inderdaad opvallend dat hy telkens die Latynse byvoeglike naamwoord arcanus verbind aan God se voorsienigheidshandelinge $^{8}$. Hy handhaaf deurgaans die siening van ' $n$ bepaalde verborgenheid in God se bestiering. Ons word so deur die verborge

Vgl Potgieter (2002:101 vv). 
raadsplan van God (arcano Dei consilio) geregeer, dat niks sonder sy medewete en sy wil met ons kan gebeur nie (Inst 1.16.3; OS III, 192).

Hierdie oortuiging van Calvyn het teoloë soms laat vra of hy nie ' $\mathrm{n}$ al te maklike oplossing vind in die "verborge wil" van God nie. Dowey sien onder meer sy voorsienigheidsleer as "permeated in an almost uncanny manner with the immediate presence of a mysterious will” (Dowey 1947:7). Berkhof praat selfs van 'n "vlucht in de onbegrijpelijkheid van God” (Berkhof 1973:229). Ook König staan krities hierteenoor:

As Calvyn nie kan begryp hoe God alles (dus ook rampe, PCP) in besonderhede kan voorbeskik maar tog nie daarvoor verantwoordelik is nie, beroep hy hom op die verborgenheid van God se Raad ... Uiteindelik lyk dit dan of die verborge Raad van God belangriker is as sy openbaring! (König 2001:197; vgl ook König 2002:70).

Ek meen egter dat ' $n$ mens met reg sou kon vra of daar enige dwingende argument is waarom God se openbaring aan die mens voorrang moet kry bo dit wat Hy nie openbaar nie. Calvyn sê immers uitdruklik dat ons daaroor moet nadink dat die lig wat God bewoon, nie sonder rede ontoeganklik genoem word nie (Inst 1.18.3). So lank as ons nog in die liggaam leef, sal ons nooit die diepste geheimenisse van God kan ken nie (Komm 1 Tim 6:16; CO 52, 332). Hy sê ook dat daar in die boek Job 'n onderskeiding gemaak word waarvan terdeë kennis geneem moet word, naamlik tussen die ondeurgrondelike wysheid van God wat vir die mens verbode terrein is, en die wysheid wat in die Wet aan ons gegee word. Ons behoort te onderskei tussen die diepsinnige en bewonderenswaardige geregtigheid (van God), wat nie deur die menslike intellek omvat kan word nie, en die reg wat in die Wet voorgeskryf word vir die reëling van die mens se lewe (Calvin 1998:56).

Op grond van die Heilige Skrif sou ons sonder twyfel kon sê dat daar enersyds in die handelinge van God ' $n$ geopenbaarde geregtigheid is, maar andersyds ook ' $n$ verborge geregtigheid. Ek wil met Bohatec saamstem dat ons hierdie verborge geregtigheid met ons beperkte insig nie kan verstaan nie (vgl Bohatec:146-7). Met verwysing na Calvyn se preke oor die boek Job, stel Schreiner dit trouens ook as sy oortuiging dat die hervormer se siening gekenmerk word deur ' $n$ herhalende spanning tussen Goddelike openbaring en 
Goddelike verborgenheid (Schreiner 1994:94). Dit word ook deur Johan Heyns as grondliggend beskou:

Gods beskikkinge en beslissinge in die geskiedenis en die verweefdheid van sy dade is van so ' $n$ aard dat die beperkte menslike verstand die diepte daarvan nooit, ooit kan deurgrond nie ... Wat die mens dus nie mag doen nie, is om, gedring deur sy natuurlike nuuskierigheid, méér te wil weet as wat deur openbaring aan hom bekend gemaak is” (Heyns 1988:164).

Naas die verborgenheid in die handelinge van God wat vir ons insig en verstand te diep is, stel Calvyn in 'n preek oor Job 31:1-4 ook ons eie verantwoordelikheid wat in ons optrede nie los staan van God se voorsienigheid nie (vgl Potgieter 1998:48).

Wat Job dus hier doen, is om te verklaar dat hy God gelowig gedien het en dat sy ervaring van sulke vreeslike en geweldige ellendes nie die gevolg is van kwaad wat hy gedoen het nie, maar van een of ander geheime rede wat aan God bekend is, wat die mens nie kan ken of onderskei nie (Preek oor Job 31:1-4; CO 34, 623).

\section{GEVOLGTREKKING}

Die noue verband wat Johannes Calvyn gelê het tussen enige vorm van rampspoed en die mens se verdorwenheid was al dikwels die voorwerp van ernstige kritiek. Dat hy soms ook geworstel het met die konsekwensie van hierdie siening, is duidelik uit sy geskrifte. Die sola scriptura-stelreël van die reformasie was vir hom egter deurslaggewend. Omdat versoening tussen dié benadering en menslike logika egter besonder problematies is, het belydenis op grond van die Skrifopenbaring vir hom uitgestyg bo menslike verstaan. Dit sal ook nie maklik wees om te bewys dat Calvyn se hermeneutiek bedenklik was nie. Wie die hervormer van Genéve dus kritiseer oor sy voorsienigheidsleer, mag homself geredelik op die weg van Skrifkritiek bevind. Van Genderen wys na my mening tereg daarop dat daar maar altyd mense is - ook teoloë - wat by die aanskoue van katastrofale en traumatiese gebeure nie meer gemaklik is met wat die Skrif oor sulke dinge sê nie. Hoe tragies wêreldgebeure ookal mag wees, gee dit nie aan die teologie die reg om ' $n$ hersiening van die Bybelse voorsienigheidsleer aan die hand te doen nie (Van Genderen en Velema 1992:270). 
God se voorsienigheid moet sonder twyfel gesien word as ' $n$ grondmotief vir die verloop van die geskiedenis. Rampspoed kan ook nie losgemaak word van die sondeval nie. Die leer van God as Skepper impliseer die goedheid van die skepping. Dit beteken egter nie dat die skepping tans volmaak is nie. Dit is, trouens, 'n essensiële onderdeel van die Christelike sondeleer dat die wêreld afgewyk het van die baan waarop God dit geplaas het in sy skeppingswerk. MacGrath stel dit so dat die wêreld wat ons sien nie die wêreld is wat deur God bedoel is nie (McGrath 1994:235). Ons kan inderdaad sê dat alles onder die beskikking van God gebeur - ook daar waar Hy in reg en geregtigheid met oordeel tref. Die oordeel word egter steeds getemper deur sy genadige weerhouding van soveel erger rampe. Sy weldade oortref die teëspoed, trouens, by verre.

Vir Calvyn was ingrypende natuurgebeure nie net ' $n$ teken van God se (al)mag nie, maar in die geval van rampspoed ook van sy oordeel oor die kwaad. Die oorsaak van alle rampspoed moet juis gesoek word in hierdie oordeel van God oor die sonde en in die eerste instansie oor die sondeval - "die hele orde van die natuur is ondergrawe deur die mens se val” (Komm Gen 3:19; CO 23, 75; vgl Komm Rom 8:20; CO 49, 152). Hy erken wel dat rampgebeure ' $n$ natuurlike oorsaak kan hê, maar ook dit val nie buite die bestiering van God nie. Selfs as Hy iets toelaat, bly dit 'n bewuste handeling van God.

Ek kom terug na Berkhof se kritiek op die gedagte van rampspoed as 'n gevolg van die sondeval. Dit is 'n tipiese voorbeeld van denke oor God in terme van menslike kategorieë. Hy sê natuurlik tereg dat die paleontologie duidelik uitwys dat katastrofale natuurgebeure lank voor die bestaan van die mens op aarde plaasgevind het. Dan laat hy volg dat daardie natuurrampe dus nie die gevolg van die sondeval kon wees nie. In dié gevolgtrekking maak hy egter die ewige bestaan van God afhanklik van tydsverloop in menslike kategorieë. Ek sou 'n paralelle toepassing wou maak: Net soos die versoeningswerk van Christus ewe effektief was vir gelowiges vóór en ná sy kruisdood, kon die sondeval ook effek gehad het vóór en ná die gebeure in die tuin van Eden. Van de Beek sê ook heeltemal tereg dat as ons tot die geheimenisse van God se voorsienigheid probeer deurdring, ons die geweldige kategoriese verskil tussen God en mens ontken (Van de Beek 2002:174; vgl Partee 1977:41). 
Ons moet dus weet dat daar in God se voorsienigheid ' $n$ verborgenheid is wat vir ons menslike insig heeltemal ontoeganklik is. Wat ons nie kan verstaan nie, kan ons egter tog op grond van wat wel aan ons geopenbaar is, tot belydenis van God se liefde en geregtigheid bring. Ons sou so ver kon gaan om te sê dat God rampspoed toelaat en dit selfs wil toelaat, maar verder as dit kan ons nie kom nie; selfs in die Bybel kla gelowiges daaroor dat hulle die rampe wat oor hulle kom, nie kan verstaan nie; hulle worstel ook met God daaroor (Van Genderen 1988:53 v). Dit is bloot die mens se gebrekkige insig wat daartoe lei dat mense bepaalde gebeure eerder wil sien as buite God se bestiering.

Alhoewel Calvyn nooit in tegniese $\sin$ ' $n$ teodisee ontwikkel nie, wil hy ten minste 'n rede vir die "vreemde" handelinge van God aandui. Op grond van die Skrifopenbaring sien hy dit as 'n middel om ons tot ootmoed en gehoorsaamheid te beweeg, en veral om ons deur beproewing na Hom terug te bring (Potgieter 1998:49).

In sy pastorale empatie met mense wat onder rampspoed ly, kom die Christologiese perspektief van Calvyn se teologie telkens na vore. Omdat ons gebind is aan Christus wat self bittere lyding geken het - 'n plaasbekledende lyding wat ons net so min kan verklaar moet ons ootmoed ook gepaard gaan met geduld en volharding in die hoop op die trou van God. Want - so sê 'n Nederlandse kollega "het kruis en de opstanding laten zien, wat God aan het kwaad gedaan heeft. In de verlengde daarvan ligt wat hij straks gaan doen” (Van Genderen en Velema 1992:288). Op geen manier kan ons met menslike logika verklaar hoe dit die wil was van die Vader wat sy Seun liefhet (Joh 3:35; 5:20) om Hom onskuldig te laat ly tot die dood aan die kruis. Ewe min kan ons vanuit ons insig verklaar hoe daar tog harmonie kan wees tussen God wat liefde is en sy voorsienigheidshandelinge wat dikwels ook vir mense lyding inhou. Ons kan beide maar net aanvaar deur die geloof wat ' $n$ genadegawe van God is.

Om terug te kom by die kernvraag: Watter plek het natuurrampe binne die voorsienigheid van God? Ek meen dat ons op grond van wat die Here in sy Woord geopenbaar het, minstens die volgende kan sê:

- $\quad$ Dat die Kerk nie in die formulering van sy verskillende belydenisse sedert die 2e eeu gefouteer het deur God as die Almagtige te erken nie; 
- $\quad$ dat die tradisionele siening in die Dogmatiek dat die almag van God beteken dat Hy enigiets kan doen wat Hy wil, gehandhaaf kan word;

- dat daar niks in God se skepping is waaroor Hy nie beheer het nie;

- $\quad$ dat die hervormer van Genéve korrek wat in sy siening dat daar naas die aspekte van die voorsienigheid wat God aan ons geopenbaar het, ook aspekte is wat Hy in hierdie bedeling vir ons verborge hou;

- $\quad$ dat ons ernstig sal fouteer as ons die voorsienigheidshandelinge van die ewige God wil beoordeel in terme van tydgebonde menslike kategorieë;

- $\quad$ dat natuurrampe en die rampspoed en lyding wat daarmee saamgaan gesien moet word as die regverdige oordeel van God oor die sonde waaraan die mensdom skuldig is;

- $\quad$ dat die oordeel wat die skepping tref ten volle oorskadu word deur die liefde van God wat Hy ons aanbied in die soenverdienste van sy Seun Jesus Christus.

Mag ek dus afsluit met ' $n$ aanhaling uit Johan Heyns se Dogmatiek:

Sy heerskappy is waarlik nie deursigtig te maak vanuit die moderne lewensgevoel nie. Daarvoor sal ons elders moet gaan soek. “... soos bv in die lewensgeskiedenis van Jesus Christus. En daarvan lees ons in die Heilige Skrif. Die voorsienigheid van God as sy blywende en rigtingewende betrokkenheid by sy skepping, is dus ' $n$ belydenis van mense wat wel nie sien nie, maar tog weet en glo dat God die werke van sy hande nie laat vaar nie, maar dit veilig en sonder ongelukke langs die pad, tog na hul eindbestemming lei” (Heyns 1978:144).

\section{Literatuurverwysings}

Arpels-Josiah, A 2004. Nature and Human Nature in Calvin's Theology: A Prophetic Voice for Environmental Ethics. Koinonia XVI, 140-60.

Berkhof, H 1973. Christelijk Geloof. Nijkerk: Callenbach.

Berkouwer, G C 1950. De Voorzienigheid Gods. Kampen: Kok.

Bohatec, J 1936. Gott und die Geschichte nach Calvin. Philosophia Reformata (1936), 146-7. 
Calvin, J 1998a. The necessity of reforming the church. In: Books for the Ages, Selected works of John Calvin, version 1.0. Albany: Ages Software.

-, 1998b. Secret providence. In: Books for the Ages, Selected works of John Calvin,version 1.0. Albany: Ages Software.

-, 1998c. Commentary on the Prophet Daniel. In: Books for the Ages, Selected works of John Calvin,version 1.0. Albany: Ages Software.

-, 1925ff. Ioannis Calvini Opera Selecta (OS), ed. P Barth et al. Munich: Kaiser.

Calvyn, J Ioannis Calvini opera quae supersunt omnia, ed. G. Braun, E Cunitz, and E. Reuss (Braunschweig 1863-1900) (= CR 29-87).

-, 1988. Institusie van die Christelike Godsdiens 1559 (Vertaal deur H W Simpson). Potchefstroom: CJBF.

Calvyn J s.a. The Comprehensive John Calvin Collection 2.0. Rio WI: The Ages Digital Library Series.

CO. vide Calvyn J. Ioannis Calvini opera quae supersunt omnia Corpus Reformatorum (CR) Halle, Braunschweig, Berlin, Zurich, 1834-.

Dowey, E A 1947. The Knowledge of God in Calvin's theology. New York: Columbia.

Farley, B W 1988. The Providence of God. Grand Rapids: Baker.

Helm, P 1994. The Providence of God. Downers Grove: IVP.

Heyns, J A 1978. Dogmatiek. Pretoria: N G Kerkboekhandel.

-, 1988. Inleiding tot die Dogmatiek. Halfway House: N G Kerkboekhandel.

-, 1992. Hoe God nou regeer. Die Kerkbode 150(24), 4.

König, A 2001. Fokus op die 300 geloofsvrae wat mense die meeste vra. Wellington: Lux Verbi.BM.

-, 2002. God, waarom lyk die wêreld so? Wellington: Lux Verbi.BM.

Küng, H 1980. Does God exist? New York: Collins.

McGrath, A E 1994. Christian Theology. Oxford: Blackwell.

Moltmann, J 1972. Der gekreuzigte Gott. München: Kaiser.

Partee, C 1977. Calvin and Classical Philosophy. Leiden: Brill.

Potgieter, P C 1991. The Providence of God in Calvin's Correspondence. In: Calvin - Erbe und Auftrag. Hrsg. von Willem van’t Spijker. Kampen: Kok.

-, 2002. Calvyn oor God se gebruik van middele in sy voorsienigheidshandelinge. Acta Theologica 22/2, 101-113.

-, 2006. Calvyn oor natuurrampe. Acta Theologica 26/1 (ter perse).

-, 1998. Perspectives on the doctrine of providence in some of Calvin's sermons on Job. Hervormde Teologiese Studies 54/1 \& 2, 36-49.

Reuter, K 1963. Das Grundverständnis der Theologie Calvins. NeukirchenVluyn: Neukirchener Verlag des Erziehungsvereins. 
Saxer, E 1980. Vorsehung und Verheissung Gottes. Zürich: Theologischer Verlag.

Schreiner, S E 1986. “Through a mirror dimly”: Calvin's Sermons on Job. Calvin Theological Journal, 21/2, 175-193.

-, 1994. Where shall wisdom be found. Calvin's exegesis of Job from medieval and modern perspectives. Chicago: University of Chicago Press.

Stauffer, R 1978. Dieu, la création et la Providence dans la prédication de Calvin. Basler und Berner Studien zur historischen und systematischen Theologie. Bern: Peter Lang.

Van de Beek, A 1996. Schepping. De wereld als voorspel voor de eeuwigheid. Baarn: Callenbach.

-, 2002. God's omnipotence and human freedom. Acta Theologica 2002, Supplementum 3, 169-186.

Van Genderen, J 1988. Actuele themas uit de Geloofsleer. Kampen: Kok.

Van Genderen, J en Velema, W H 1992. Beknopte Gereformeerde Dogmatiek. Kampen: Kok.

Wiersinga, H 1975. Verzoening met het lijden? Baarn: Ten Have. 